\title{
Serum magnesium at 18-20 weeks of gestation: can it be a predictor of gestational hypertension and fetomaternal outcome?
}

\author{
Sasikala Kathiresan ${ }^{1}$, Agalya Angelina Sanjevrajah ${ }^{1 *}$, Jeyashree Kathiresan ${ }^{2}$
}

\author{
${ }^{1}$ Department of Obstetrics and Gynecology, ${ }^{2}$ Department of Preventive and Social Medicine, Velammal Medical \\ College Hospital and Research Institute, Anuppanadi, Madurai, Tamil Nadu, India
}

Received: 21 January 2020

Accepted: 26 February 2020

*Correspondence:

Dr. Agalya Angelina Sanjevrajah,

E-mail: cmcdr.angelina@gmail.com

Copyright: (C) the author(s), publisher and licensee Medip Academy. This is an open-access article distributed under the terms of the Creative Commons Attribution Non-Commercial License, which permits unrestricted non-commercial use, distribution, and reproduction in any medium, provided the original work is properly cited.

\begin{abstract}
Background: Hypertensive disorders of pregnancy (HDP) is a major cause of maternal, fetal morbidity and mortality complicating $10 \%$ of all gestations. As effective treatments are very limited, prediction of HDP occurrence is most importance. Though many biomarkers have shown relationship with HDP, serum magnesium $(\mathrm{Mg})$ has shown better predictor as involved in maintaining vascular contractility, tone. This study is intended to analyse incidence of GHT and fetomaternal outcome in pregnant women with normal and low serum magnesium level measured at mid trimester (18-20 weeks).

Methods: A total of 105 consecutive singleton pregnant women in between 18-20 weeks of gestation attending OBG outpatient department were enrolled. After obtaining the informed consent, structured proforma was used to collect demographic, clinical details. Serum magnesium was measured by the colorimetric method and study participants were divided into two groups based on $\mathrm{Mg}$ cut off $1.5 \mathrm{mg} / \mathrm{dl}$ and followed up throughout pregnancy for fetomaternal outcome.

Results: This study results revealed that 35.2\% (37/105) pregnant women had serum $\mathrm{Mg}$ level $<1.5 \mathrm{mg} / \mathrm{dl}$ and mean value of $\mathrm{Mg}$ of all participant is $1.7 \mathrm{mg} / \mathrm{dl}$, just above the lower limit. During follow-up of these two groups, statistically significant correlation between serum Mg levels $(<1.5 \mathrm{mg} / \mathrm{dl})$ with GHT $(8 / 12)$ occurrence and pre term birth was found. Other fetomaternal outcome not had significant correlation.

Conclusions: As per the findings, serum Mg concentration measurement in between 18-20 weeks can be considered as a one of the predictors for subsequent occurrence of maternal outcome of GHT and fetal outcome of pre-term birth.
\end{abstract}

Keywords: Fetomaternal outcome, Gestational hypertension, Predictor, Serum magnesium

\section{INTRODUCTION}

Hypertensive disorders of pregnancy (HDP) such as gestational hypertension (GHT), pre-eclampsia (PE) are the frequently encountered complications during pregnancy, complicating up to $10 \%$ of gestations. ${ }^{1,2}$ Globally HDP remains one of the most common cause of maternal, fetal morbidity and mortality. ${ }^{3,4}$ Prevalence of GHT and PE in developing countries is $3-10 \%$ and $4-$ $18 \%$ respectively. ${ }^{5-7}$ Women with HDP is associated with increased risks of placental abruption, cerebrovascular events, disseminated intravascular coagulation and leading to $10-15 \%$ of maternal death. ${ }^{4,8}$

Fetus of these mothers are having the increased risk of prematurity, intrauterine growth retardation and death. ${ }^{9,10}$ The prevalence of maternal, fetal complications associated with HDP vary by region and healthcare facility type. ${ }^{11,12}$ Rate of HDP is likely to increase along with obesity and metabolic syndrome in women of reproductive age group. As effective treatments are 
currently limited for HDP, prediction of HDP occurrence is at most importance to prevent the complications. ${ }^{8,13}$

Combination of maternal demographic characteristics, medical and obstetric history, uterine artery pulsatility index, mean arterial pressure and maternal serum pregnancy- associated plasma protein-A and placental growth factor at 11-13 weeks gestation are all used as predictor of HDP. ${ }^{14-16}$ Also results from various studies have shown the relation-ship between hypertensive disorders of pregnancy and serum electrolytes particularly calcium and magnesium. ${ }^{17,18}$

Magnesium is an important cofactor in a number of biochemical reactions in synthesis of proteins, nucleic acids and metabolism of carbohydrates and also in balancing oxidative stress. Apart from that, $\mathrm{Mg}$ is important for the normal muscular functions, regulation of potassium, calcium and sodium transport across membranes, maintain vascular contractility and tone. The deficit of $\mathrm{Mg}$ is accompanied with the increased risk of endothelial dysfunction and hypertension. ${ }^{19}$ The recommended $\mathrm{Mg}$ amount on a daily basis increases by $30 \%$ during pregnancy and in developing countries as many as $45 \%$ of pregnant women are $\mathrm{Mg}$-deficient. ${ }^{20}$

Many studies that have looked into $\mathrm{Mg}$ serum concentration in pregnant women with the diagnosis of preeclampsia, but very few studies measured the magnesium level as a base line since the beginning of their pregnancy. ${ }^{11,12,15,18}$ And also role of magnesium deficiency in the development of adverse outcomes in terms of both maternal and fetal health was insufficiently studied in the environment.

So, this study is intended to analyse the incidence of GHT and fetomaternal outcome in pregnant women with normal and low serum magnesium level measured at mid trimester (18-20 weeks).

\section{METHODS}

This prospective study was carried out in the department obstetrics and gynecology of this tertiary care centre, spanned over a period of 6 months (October 2017 to March 2018) after attaining the Institutional Ethics Committee approval (IEC Ref No.: VMCIEC/55/2017).

After getting the written informed consent 105 consecutive singleton pregnant women in between 18-20 weeks of gestation attending outpatient department of OBG were enrolled in the study. Pregnant woman with chronic hypertension, pre-existing diabetes, proteinuria, renal diseases and those not willing for participation were excluded from the study. Structured proforma was used to collect demographic and clinical details like age, parity, gestational age of pregnancy based on last menstrual period or ultra sound data and previous existing illness. Blood pressure and urine protein were monitored as a routine to rule out HDP. New-onset hypertension (systolic blood pressure (SBP) $\geq 140 \mathrm{mmHg}$ or diastolic blood pressure (DBP) $\geq 90 \mathrm{mmHg}$ on at least two occasions with an interval of 6 hours or more) and proteinuria (urinary excretion of $\geq 300 \mathrm{mg}$ of proteins within 24 hours) after 20 weeks of gestation was labelled as $\mathrm{PE}$, and only elevated $\mathrm{BP}$ without proteinuria was labelled as GHT.

Five milliliters of venous blood sample was collected in red vacutainer from participant's antecubital vein and immediately transferred to department of Biochemistry where blood samples were allowed to clot at room temperature and then centrifuged at $1500 \mathrm{rpm}$ for 15 minutes for serum separation. Serum magnesium was measured by the colorimetric method using Xylidyl blue with ATCS auto-analyser. Based on the serum Mg level study participants were divided into 2 groups. One with the serum $\mathrm{Mg}$ level of $<1.5 \mathrm{mg} / \mathrm{dl}$ and another one as serum $\mathrm{Mg}$ level of $\geq 1.5 \mathrm{mg} / \mathrm{dl}$.

Subsequently all the participants were followed-up till delivery and data recording mode of delivery, development of GHT/PE, maternal and fetal outcomes/complications were documented in the same structured proforma.

\section{Statistical analysis}

The data were analyzed using the SPSS software version 15.0 and expressed in terms of mean, standard deviation, and percentage. Continuous variables were compared with the Student's t-test and paired sample t-test. A p value of $<0.05$ was considered as statistically significant.

\section{RESULTS}

A total of 105 singleton pregnant women were included in this study. All of them were in the age group of 18-37 years (mean age $\pm \mathrm{SD}=24.8 \pm 3.6$ ), with the gestation period between 18-20 weeks (mean $\pm \mathrm{SD}=19.2 \pm 0.7$ ). Half of the participants were primi gravida and another half were multi gravida. Mean serum $\mathrm{Mg}$ level among participants were $1.71 \pm 0.55 \mathrm{mg} / \mathrm{dl}$ (Table 1 ).

Table 1: Demographic and clinical characteristics of the participants.

\begin{tabular}{|lll|}
\hline & Mean/N & SD $/ \%$ \\
\hline Age (years) & 24.86 & 3.56 \\
\hline Gravida & & \\
\hline Primi & 52 & 49.5 \\
\hline Multi & 53 & 51.5 \\
\hline Serum $\mathrm{Mg}(\mathrm{mg} / \mathrm{dl})$ & 1.71 & 0.55 \\
\hline
\end{tabular}

This study participants were divided into 2 groups based on the serum $\mathrm{Mg}$ level cut off of $1.5 \mathrm{mg} / \mathrm{dl}$. Among the 105 participants, 37 pregnant women $(35.2 \%)$ had the serum $\mathrm{Mg}$ level below $1.5 \mathrm{mg} / \mathrm{dl}$ were categorised as Group I and 68 pregnant women $(64.8 \%)$ had the serum 
$\mathrm{Mg}$ level $\geq 1.5 \mathrm{mg} / \mathrm{dl}$ were categorised as Group II (Figure 1).

During the next visit, total of 12 pregnant women (8 pregnant women from Group I and 4 from Group II) has developed the GHT. Analysing GHT development among both the groups revealed that there were statistically significant correlation between serum Mg levels of less than $1.5 \mathrm{mg} / \mathrm{dl}$ with GHT occurrence with the $\mathrm{p}$ value of $0.015(\mathrm{p}<0.05)($ Table 2$)$.

In Group I among 37 pregnant women who had serum Mg level $<1.5 \mathrm{mg} / \mathrm{dl}$, 9 pregnant women had urinary albumin positive, 2 developed gestational diabetes, 6 had oligohydramnios and 2 had meconium stained liquor. Analysing fetal complications 3 had IUGR and another 3 had preterm babies.

In Group II among 68 pregnant women who had serum $\mathrm{Mg}$ level $\geq 1.5 \mathrm{mg} / \mathrm{dl}, 10$ pregnant women had urinary albumin positive, 9 pregnant women developed gestational diabetes, 8 had oligohydramnios and 3 had meconium stained liquor. Analysing fetal complications 3 had IUGR and another 2 had preterm babies.

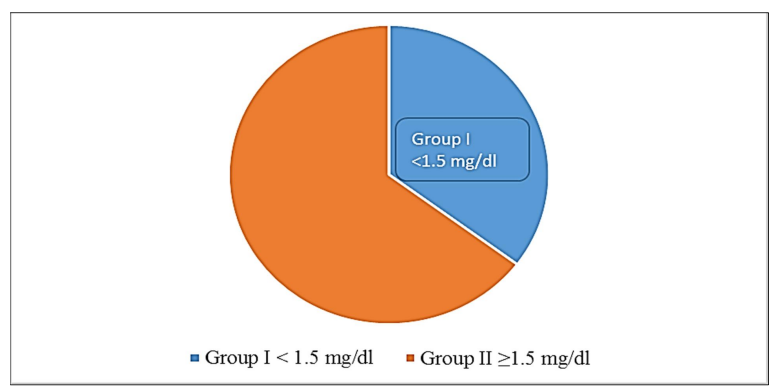

Figure 1: Participant group based on serum magnesium cut off $1.5 \mathrm{mg} / \mathrm{dl}$.

Analysing correlation between serum $\mathrm{Mg}$ level with fetomaternal complications revealed that there were no statistically significant correlation found between these two groups except with preterm birth (Table 3).

Table 2: Correlation of serum Mg level with GHT occurrence.

\begin{tabular}{|c|c|c|c|c|c|c|c|}
\hline & & \multicolumn{2}{|c|}{ Group I serum $\mathrm{Mg}<1.5 \mathrm{mg} / \mathrm{dl}$} & \multicolumn{2}{|c|}{ Group II serum $\mathrm{Mg} \geq 1.5 \mathrm{mg} / \mathrm{dl}$} & Chisq/t & p value \\
\hline & & Mean/N & $\mathrm{Sd} / \%$ & Mean/N & $\mathrm{Sd} / \%$ & \multirow{3}{*}{5.864} & \multirow{3}{*}{0.015} \\
\hline \multirow{2}{*}{ GHT } & No & 29 & 31.2 & 64 & 68.8 & & \\
\hline & Yes & 8 & 66.7 & 4 & 33.3 & & \\
\hline
\end{tabular}

Table 3: Correlation of serum Mg level with fetomaternal complication.

\begin{tabular}{|c|c|c|c|c|c|c|c|}
\hline & & \multicolumn{2}{|c|}{ Group I serum $\mathrm{Mg}<1.5 \mathrm{mg} / \mathrm{dl}$} & \multicolumn{2}{|c|}{ Group II serum $\mathrm{Mg} \geq 1.5 \mathrm{mg} / \mathrm{dl}$} & \multirow[t]{2}{*}{ Chisq/t } & \multirow[t]{2}{*}{ p value } \\
\hline & & Mean/N & $\mathrm{SD} / \%$ & Mean/N & SD $/ \%$ & & \\
\hline \multirow{2}{*}{ Urine Alb } & No & 28 & 32.6 & 58 & 67.4 & \multirow{2}{*}{1.496} & \multirow{2}{*}{0.221} \\
\hline & Yes & 9 & 47.4 & 10 & 52.6 & & \\
\hline \multirow{2}{*}{ GDM } & No & 35 & 37.2 & 59 & 62.8 & \multirow{2}{*}{1.566} & \multirow{2}{*}{0.211} \\
\hline & Yes & 2 & 18.2 & 9 & 81.8 & & \\
\hline \multirow{2}{*}{ Oligo hydr } & No & 31 & 34.1 & 60 & 65.9 & \multirow{2}{*}{0.411} & \multirow{2}{*}{0.522} \\
\hline & Yes & 6 & 42.9 & 8 & 57.1 & & \\
\hline \multirow{2}{*}{ MSL } & No & 35 & 35 & 65 & 65 & \multirow{2}{*}{0.052} & \multirow{2}{*}{0.819} \\
\hline & Yes & 2 & 40 & 3 & 60 & & \\
\hline \multirow{2}{*}{ IUGR } & No & 34 & 34.3 & 65 & 65.7 & \multirow{2}{*}{0.608} & \multirow{2}{*}{0.436} \\
\hline & Yes & 3 & 50 & 3 & 50 & & \\
\hline \multirow{2}{*}{ Preterm } & No & 27 & 34 & 66 & 66 & \multirow{2}{*}{6.432} & \multirow{2}{*}{0.012} \\
\hline & Yes & 10 & 60 & 2 & 40 & & \\
\hline
\end{tabular}

***Alb: Albumin, Oligo hydr: Oligo hydramnios, MSL: Meconium stained liquor, IUGR: Intra uterine growth retardation.

\section{DISCUSSION}

Studies carried out on animal revealed that hypomagnesemia had marked effects on processes of parturition, postpartum uterine involution, fetal growth and development. ${ }^{21,22}$ Serum optimum concentration of Magnesium depends on an adequate intake, absorption and excretion along with availability of $\mathrm{Mg}$ from bones. Recommended amount of $\mathrm{Mg}$ intake on daily basis is 310-320 mg/day. ${ }^{19}$ As pregnancy is associated with hemodilution, increased renal clearance and demand by growing foetus, recommended $\mathrm{Mg}$ amount increases $30 \%$ on daily basis during the pregnancy. Literature also suggests that over $50 \%$ of reproductive age group do not 
take the recommended amount of $\mathrm{Mg} .{ }^{11,18}$ The role that $\mathrm{Mg}$ in PE pathogenesis has not been completely elucidated yet. Though contradicting results obtained from different studies, due to its vasodilatory properties $\mathrm{Mg}$ can improve the endothelial function and can reduce placental ischemia, which in turn reduce the prevalence of PE. ${ }^{19}$

Mostly evaluation of serum $\mathrm{Mg}$ concentration was done in cases where pregnant women had already been diagnosed with PE. In pregnancy determination of serum $\mathrm{Mg}$ level is rarely done as a routine clinical protocols though some studies claim that hypomagnesemia is present in as many as $\sim 45 \%$ pregnant women in certain regions. ${ }^{12,23}$ So this study has planned to determine serum concentration of $\mathrm{Mg}$ in pregnant women attending this OPD in between 18-20 weeks gestation (i.e., before development of PE which usually occur after 20 weeks).

This study results revealed that $35.2 \%(37 / 105)$ pregnant women enrolled in this study had serum $\mathrm{Mg}$ level $<1.5$ $\mathrm{mg} / \mathrm{dl}$ which was concordance with the study finding of Pathak et al, who also reported that $43.6 \%$ of pregnant women in India had hypomagnesemia. ${ }^{24}$ Also, this study population mean value of serum $\mathrm{Mg}$ is $1.7 \mathrm{mg} / \mathrm{dl}$, just above the lower limit. This may be attributed to increased metabolic demand due to growing foetus along with poor nutrition in this setup.

During the follow-up of these two groups, 12 pregnant women $(11.4 \%)$ developed GHT. Of which two third cases $(8 / 12)$ from Group I (serum $\mathrm{Mg}$ level $<1.5 \mathrm{mg} / \mathrm{dl}$ ). In comparing both the groups, $21.6 \%(8 / 37)$ of pregnant women developed GHT in Group I; on the other hand, $0.06 \%(4 / 64)$ of pregnant women only developed GHT in Group II. Analyzing GHT development among both the groups revealed that there were statistically significant correlation between serum $\mathrm{Mg}$ levels of less than 1.5 $\mathrm{mg} / \mathrm{dl}$ with GHT occurrence with the $\mathrm{p}$ value of 0.015 ( $\mathrm{p}$ $<0.05$ ). This study finding revealed that low serum $\mathrm{Mg}$ level during the 18-20 weeks of gestation can be used as one of the predictors of GHT occurrence.

Analyzing the other maternal outcome among these two groups revealed that there were no statistically significant correlation found between serum $\mathrm{Mg}$ level and other maternal outcome like gestational diabetes, oligohydramnios and meconium stained liquor. But analyzing the fetal outcome revealed that preterm birth occurrence had the statistically significant correlation with the serum $\mathrm{Mg}$ levels of less than $1.5 \mathrm{mg} / \mathrm{dl}$ with the $p$ value of $0.012(p<0.05)$ as nearly one third of the pregnant women (10/37) in Group I had the preterm birth. This study results are in concordance with Shahid et al, and Enaruna et al, who also reported the same. ${ }^{12,25}$ This may attribute due to action of magnesium in pre-term labor attenuation by competing with intracellular calcium at its binding sites, thereby decreasing muscle contractility and stabilizing the membrane potential. This study finding revealed that low serum $\mathrm{Mg}$ level during the 18-20 weeks of gestation can be used as one of the predictors of preterm birth babies.

On analyzing IUGR with serum $\mathrm{Mg}$ level revealed that there was no statistically significant correlation in between these two. This may be due to the symphysiofundal height measurement what we have used. Ultrasound diagnosis of IUGR may be a better parameter to analyze with respect to magnesium deficiency.

\section{CONCLUSION}

According to the results obtained from this study, serum $\mathrm{Mg}$ concentration measurement in between 18-20 weeks can be considered as a one of the predictors for subsequent occurrence of maternal outcome of GHT. This study results were consistent with the hypothesis that $\mathrm{Mg}$ deficiency can account for etiopathogenesis of PE. Besides, serum Mg concentration could also play an important role in predicting the fetal outcome of preterm baby. Taking this into account, determination of serum $\mathrm{Mg}$ concentration should be included as a routine practice before occurrence of HDP (before 20 weeks).

\section{Implication}

Predicting the HDP is at most importance to prevent the maternal, fetal complications associated with HDP. As this study results shown serum $\mathrm{Mg}$ concentration in between 18-20 weeks of gestation can be used as a predictor of HDP. This will be helpful in taking the preventive measures like nutritional counselling to maintain the positive $\mathrm{Mg}$ balance and improving the socio-economic status through education and $\mathrm{Mg}$ supplementation or consumption of a Mg-rich diet to all pregnant woman in this study setup to prevent the fetomaternal outcome of HDP.

\section{ACKNOWLEDGMENTS}

Authors would like to thank Dr. Mohanty P, Professor and HOD, biochemistry for his constant valuable support in collection of data.

Funding: No funding sources Conflict of interest: None declared

Ethical approval: The study was approved by the Institutional Ethics Committee (Ref No.: VMCIEC/55/2017)

\section{REFERENCES}

1. Lai C, Coulter SA, Woodruff A. Hypertension and pregnancy. Tex Heart Inst J. 2017;44(5):350-1.

2. Magee LA, Helewa M, Rey E, Diagnosis, evaluation, and management of the hypertensive disorders of pregnancy. J Obstet Gynaecol Can JOGC J Obstet Gynecol Can. 2008;30(3 Suppl):S1-2. 
3. Khumanthem PD, Chanam MS, Samjetshabam RD. Maternal mortality and its causes in a tertiary center. J Obstet Gynaecol India. 2012;62(2):168-71.

4. You F, Huo K, Wang R, Xu D, Deng J, Wei Y, et al. Maternal mortality in Henan Province, China: changes between 1996 and 2009. PloS One. 2012;7(10):e47153.

5. Upadya M, Rao ST. Hypertensive disorders in pregnancy. Indian J Anaesth. 2018;62(9):675-81.

6. Mehta B, Kumar V, Chawla S, Sachdeva S, Mahopatra D. Hypertension in pregnancy: a community-based study. Indian J Community Med Off Publ Indian Assoc Prev Soc Med. 2015;40(4):273-8.

7. Umesawa M, Kobashi G. Epidemiology of hypertensive disorders in pregnancy: prevalence, risk factors, predictors and prognosis. Hypertens Res Off J Jpn Soc Hypertens. 2017;40(3):213-20.

8. Lo JO, Mission JF, Caughey AB. Hypertensive disease of pregnancy and maternal mortality. Curr Opin Obstet Gynecol. 2013;25(2):124-32.

9. Backes CH, Markham K, Moorehead P, Cordero L, Nankervis CA, Giannone PJ. Maternal preeclampsia and neonatal outcomes. J Preg. 2011:Article ID 214365.

10. Takaya J, Yamato F, Kaneko K. Possible relationship between low birth weight and magnesium status: from the standpoint of "fetal origin" hypothesis. Magnes Res. 2006;19(1):63-9.

11. Tavana Z, Hosseinmirzaei S. Comparison of maternal serum magnesium level in pre-eclampsia and normal pregnant women. Iran Red Crescent Med J. 2013;15(12):2.

12. Enaruna NO, Ande ABA, Okpere EE. Clinical significance of low serum magnesium in pregnant women attending the University of Benin Teaching Hospital. Niger J Clin Pract. 2013;16(4):448.

13. Kintiraki E, Papakatsika S, Kotronis G, Goulis DG, Kotsis V. Pregnancy-Induced hypertension. Horm Athens Greece. 2015;14(2):211-23.

14. Baumann MU, Bersinger NA, Surbek DV. Serum markers for predicting pre-eclampsia. Mol Aspects Med. 2007;28(2):227-44.

15. Luo Q, Han X. Second-trimester maternal serum markers in the prediction of preeclampsia. J Perinat Med. 2017;45(7):809-16.
16. Monte S. Biochemical markers for prediction of preclampsia: review of the literature. J Prenat Med. 2011;5(3):69-77.

17. Kanagal DV, Rajesh A, Rao K, Devi UH, Shetty H, Kumari S, et al. Levels of serum calcium and magnesium in pre-eclamptic and normal pregnancy: a study from coastal India. J Clin Diagn Res JCDR. 2014;8(7):OC01-4.

18. Darkwa EO, Antwi-Boasiako C, Djagbletey R, Owoo C, Obed S, Sottie D. Serum magnesium and calcium in preeclampsia: a comparative study at the Korle-Bu Teaching Hospital, Ghana. Integr Blood Press Control. 2017;10:9.

19. Wolf FI, Trapani V, Simonacci M, Ferré S, Maier JAM. Magnesium deficiency and endothelial dysfunction: is oxidative stress involved? Magnes Res. 2008;21(1):58-64.

20. Kass L, Weekes J, Carpenter L. Effect of magnesium supplementation on blood pressure: a meta-analysis. Eur J Clin Nutr. 2012;66(4):411-8.

21. Venu L, Padmavathi IJN, Kishore YD, Bhanu NV, Rao KR, Sainath PB, et al. Long-term effects of maternal magnesium restriction on adiposity and insulin resistance in rat pups. Obes Silver Spring Md. 2008;16(6):1270-6.

22. Rosner JY, Gupta M, McGill M, Xue X, Chatterjee PK, Yoshida-Hay M, et al. Magnesium deficiency during pregnancy in mice impairs placental size and function. Placenta. 2016;39:87-93.

23. Morton A. Hypomagnesaemia and pregnancy. Obstet Med. 2018;11(2):67-72.

24. Pathak P, Kapoor SK, Kapil U, Dwivedi SN. Serum magnesium level among pregnant women in a rural community of Haryana State, India. Eur J Clin Nutr. 2003;57(11):1504-6.

25. Shahid AR, Hosna AU, Tahmina HZ. Hypomagnesaemia in pregnancy: a predictor of preterm labour. J Dhaka Med Coll. 2010;19(1):51-7.

Cite this article as: Kathiresan S, Sanjevrajah AA, Kathiresan J. Serum magnesium at 18-20 weeks of gestation: can it be a predictor of gestational hypertension and fetomaternal outcome?. Int $\mathbf{J}$ Reprod Contracept Obstet Gynecol 2020;9:1402-6. 